\title{
Long-term Prognosis following Ventricular Fibrillation in Acute Ischaemic Heart Disease
}

\author{
B. T. MCNAMEE, ${ }^{*}$ M.B., M.R.C.P.GLASG. ; T. J. ROBINSON,* M.D., M.R.C.P. ; A. A. J. ADGEY, † M.B., M.R.C.P. \\ M. E. SCOTT, ${ }^{*}$ M.D., B.SC., M.R.C.P. ; J. S. GEDDES, ${ }^{*}$ M.D., M.R.C.P. ; J. F. PANTRIDGE, $\ddagger$ M.D., F.R.C.P.
}

\begin{abstract}
Cummary: Of 160 patients who survived ventricular $\checkmark$ fibrillation complicating acute ischaemic heart disease, 80 had had a clinically mild coronary attack. Most of the long-term survivors had ventricular fibrillation within 24 hours of the onset of symptoms. The longterm prognosis of the survivors was similar to that of patients whose myocardial infarction was not complicated by ventricular fibrillation. Those patients who survived ventricular fibrillation which occurred within four hours of the onset of symptoms were younger, usually had had a mild coronary attack, and had the most favourable longterm prognosis. The number of episodes of ventricular fibrillation did not affect adversely the long-term prognosis. Of those who at the time of review were eligible to work, $86 \%$ were fit to work and $68 \%$ were actually at work.
\end{abstract}

\section{Introduction}

Ventricular fibrillation has often been successfully corrected in coronary care units (Day, 1963; Meltzer and Kitchell, 1966; Pantridge and Geddes, 1966; Lawrie et al., 1968). Furthermore, the correction of ventricular fibrillation outside hospital is a practicable proposition (Pantridge and Geddes, 1967; Adgey et al., 1969). In an earlier communication from this unit we reported the long-term prognosis of 50 patients who were treated for ventricular fibrillation complicating acute ischaemic heart disease (Geddes et al., 1967). In this paper we describe the long-term prognosis of 160 patients.

\section{Patients and Methods}

Among patients with ventricular fibrillation who were resuscitated by the staff of this unit during 1964 to 1 December, 1969, 173 survived to leave hospital. Of these we studied 160-126 men and 34 women-with ventricular fibrillation complicating acute ischaemic heart disease; the age of the two groups ranged from 35 to 79 (mean 58) years and 38 to 77 (mean 64) years, respectively.

Of the 151 patients who had acute myocardial infarction as previously defined (Adgey et al., 1968), $79(52 \%)$ had an anterior infarction, $66(44 \%)$ a posterior infarction, $4(3 \%)$ an anterior and posterior infarction, and 2 left bundle-branch block. In $79(52 \%)$ the attack had been clinically mild, these patients showing no significant circulatory disturbance before ventricular fibrillation; in $43(29 \%)$ it had been moderately severe with blood pressure of $90-95 \mathrm{~mm}$. Hg. systolic or significant pulmonary congestion; and in a further $29(19 \%)$ the attack was thought to have been severe on account of the considerable degree of cardiac failure. When ventricular fibrillation was the presenting feature the assessment was made 24 hours after resuscitation.

The remaining nine patients had acute coronary insufficiency with prolonged ischaemic chest pain occurring $a^{+}$ rest; the electrocardiograms, though abnormal, did not show conclusive evidence of infarction. The clinical condition in

\footnotetext{
* Senior Registrar

+ Research Fellow.

¥ Physician in Charge.

Cardiac Department, Royal Victoria Hospital, Belfast, N. Ireland.
}

these patients was mild in one, moderate in six, and severe in two.

Ventricular fibrillation occurred in 32 patients $(20 \%)$ while outside hospital, in $33(21 \%)$ while in the hospital coronary care unit; and in $95(59 \%)$ while elsewhere in the hospital (which has 1,100 beds). Documented evidence of previous myocardial infarction existed for $46(29 \%)$ patients and of angina pectoris without previous infarction for $57(36 \%)$, whereas there was no previous evidence of ischaemic heart disease for $57(36 \%)$.

Our management of ventricular fibrillation has been described previously (Pantridge and Geddes, 1966; Adgey et al., 1969). All the patients reviewed required direct current countershock; of these 119 had one episode of ventricular fibrillation and 41 repeated episodes. Of the latter 41,26 had two episodes, six had three, and nine had more than four, two of these latter having more than 100 separate episodes. Repetitive ventricular fibrillation is defined as the recurrence of the dysrhythmia half an hour or more after its removal and restoration of satisfactory circulation.

\section{Follow-up}

Of the 115 patients known to be alive in December 1969, 101 were reviewed by one of us. A detailed history regarding dyspnoea, chest pain, work record, psychiatric symptoms, and drug treatment was taken. Chest $x$-ray films were obtained in 96 patients. The serum of each of the 31 patients who were taking or had been taking procainamide within six months was examined for lupus erythematosus (L.E.) cells. Seven, including two who had emigrated, were unavailable for review, but details of their work record were available from their family doctors. A further seven patients had been discharged from hospital within two months and were not reviewed. The period of follow-up ranged from 1 to 58 (mean 15) months. The date and mode of death of 40 of the 45 patients who had died after discharge from hospital were obtained from subsequent hospital records or from their family doctors.

\section{Results}

\section{Long-term Survivors}

Most of the long-term survivors had had ventricular fibrillation soon after the onset of symptoms-96 (60\%) within 24 hours of the onset of symptoms (Table I), 46 (48\%) within two hours, and $29(30 \%)$ within one hour (Table II). Twenty of these 29 survivors had ventricular fibrillation while outside hospital. The number of potential and actual survivors at six-monthly intervals from the date of discharge from hospital is shown in Table III, while the percentage survival rates of the 160 patients is shown in Table IV, which also indicates survival related to the clinical severity. Since the number in the severe group was too small for separate analysis this and the moderate group have been considered together. The longterm prognosis of those patients who had had ventricular fibrillation complicating a clinically mild attack was significantly better than of those with a moderate or a severe attack $(\mathrm{P}<0.05)$. 
TABLE I.-Interval between Onset of Sympoms and Initial Episode of Ventricular Fibrillation in the 160 Patients

\begin{tabular}{|c|c|c|c|c|c|c|c|c|c|c|c|c|c|c|c|c|c|c|c|c|c|c|c|c|c|c|c|c|c|}
\hline $\begin{array}{l}\text { Day . . } \\
\text { No. of patients.. }\end{array}$ & $\begin{array}{l}\cdots \\
\therefore\end{array}$ & $\begin{array}{l}. \\
\cdots\end{array}$ & $\begin{array}{l}\text {. } \\
\text {. }\end{array}$ & $\begin{array}{c}1 \\
96\end{array}$ & $\begin{array}{l}2 \\
7\end{array}$ & $\begin{array}{l}3 \\
5\end{array}$ & $\begin{array}{l}4 \\
6\end{array}$ & $\begin{array}{l}5 \\
4\end{array}$ & $\begin{array}{l}6 \\
3\end{array}$ & $\begin{array}{l}7 \\
4\end{array}$ & $\begin{array}{l}8 \\
2\end{array}$ & $\begin{array}{l}9 \\
0\end{array}$ & $\begin{array}{c}10 \\
1\end{array}$ & 11 & $\begin{array}{c}12 \\
5\end{array}$ & $\begin{array}{c}13 \\
8\end{array}$ & $\begin{array}{c}14 \\
2\end{array}$ & $\begin{array}{c}15 \\
2\end{array}$ & $\begin{array}{c}16 \\
4\end{array}$ & $\begin{array}{l}17 \\
2\end{array}$ & $\begin{array}{c}18 \\
1\end{array}$ & $\begin{array}{c}19 \\
2\end{array}$ & $\begin{array}{c}20 \\
0\end{array}$ & $\begin{array}{c}21 \\
0\end{array}$ & $\begin{array}{c}22 \\
2\end{array}$ & $\begin{array}{c}23 \\
0\end{array}$ & $\begin{array}{c}24 \\
0\end{array}$ & $\begin{array}{c}25 \\
1\end{array}$ & $\begin{array}{l}26 \\
2\end{array}$ \\
\hline
\end{tabular}

TABLE II.-Interval between Onset of Symptoms and Initial Onset Ventricular Fibrillation among the 96 Patients who developed Ventricular Fibrillation within 24 Hours

\begin{tabular}{ll|l|l|l|l|l|l|l|l|l|l|l|l|l|l}
\hline No. of hours & $\cdots$ & -2 & -4 & -6 & -8 & -10 & -12 & -14 & -16 & -18 & -20 & -22 & -24 \\
No. of patients & $\cdots$ & 46 & 19 & 9 & 2 & 7 & 4 & 1 & 1 & 2 & 2 & 2 & 1 \\
\hline
\end{tabular}

TABLE III.-Number of Potential and Actual Survivors at 6-monthly Intervals TABLE III.-Number of Potential and Actual Survivors at
from the Date of Hospital Discharge

\begin{tabular}{|c|c|c|c|c|c|c|c|c|c|c|c|}
\hline Months: & 0 & 6 & 12 & 18 & 24 & 30 & 36 & 42 & 48 & 54 & 60 \\
\hline $\begin{array}{ll}\text { Potential survivors } & \ldots \\
\text { Actual survivors } & \ldots \\
\text { Deaths } & .\end{array}$ & $\begin{array}{l}160 \\
160\end{array}$ & $\begin{array}{r}130 \\
112 \\
18\end{array}$ & $\begin{array}{r}101 \\
79 \\
22\end{array}$ & $\begin{array}{l}79 \\
54 \\
25\end{array}$ & $\begin{array}{l}68 \\
46 \\
22\end{array}$ & $\begin{array}{l}48 \\
28 \\
20\end{array}$ & $\begin{array}{l}28 \\
17 \\
11\end{array}$ & $\begin{array}{r}19 \\
9 \\
10\end{array}$ & $\begin{array}{r}10 \\
6 \\
4\end{array}$ & $\begin{array}{l}6 \\
3 \\
3\end{array}$ & $\begin{array}{l}1 \\
0 \\
1\end{array}$ \\
\hline
\end{tabular}

TABLE IV.-Percentage Survival (Berkson and Gage, 1950) for the 160 Patients Related to Severity of Infarction

\begin{tabular}{|c|c|c|c|c|}
\hline Months & $\begin{array}{l}\text { Whole } \\
\text { Group } \\
\%\end{array}$ & $\begin{array}{c}\text { Mild } \\
\mathbf{A} \\
\%\end{array}$ & $\begin{array}{c}\text { Mod. } / \text { Severe } \\
\text { B } \\
\%\end{array}$ & $\begin{array}{l}\text { Difference (A-B) } \\
\text { of \% Survival } \pm \\
\text { S.E. of Difference }\end{array}$ \\
\hline $\begin{array}{r}0 \\
6 \\
12 \\
18 \\
24 \\
30 \\
36 \\
42\end{array}$ & $\begin{array}{rr}100 & (160) \\
87 & (112) \\
79 & (79) \\
71 & (54) \\
68 & (46) \\
61 & (28) \\
58 & (17) \\
46 & (9)\end{array}$ & $\begin{array}{rr}100 & (80) \\
100 & (65) \\
97 & (49) \\
90 & (32) \\
87 & (28) \\
83 & (19) \\
78 & (14) \\
65 & (7)\end{array}$ & $\begin{array}{rr}100 & (80) \\
76 & (47) \\
63 & (30) \\
54 & (22) \\
51 & (18) \\
41 & (9) \\
41 & (3) \\
14 & (2)\end{array}$ & $\begin{array}{l}24^{*}+5 \cdot 26 \\
34^{*} \pm 12 \cdot 75 \\
36^{*} \pm 15 \cdot 32 \\
36^{*} \pm 14 \cdot 77 \\
42^{*} \pm 16 \cdot 06 \\
37^{*} \pm 10 \cdot 17 \\
51^{*} \pm 13.47\end{array}$ \\
\hline
\end{tabular}

The number of patients alive is shown in parentheses.

* Significant at $\mathrm{P}<0.05$. TABLE V.-Average Age (in Years) of Patients by $S_{c x}$, Severity, and Time
Interval from Onset of Symptoms to Initial Episode of Ventricular Fibrillation. The Number in Each Group is Also Shown

\begin{tabular}{|c|c|c|c|c|c|c|}
\hline \multirow{3}{*}{ Severity } & \multirow{3}{*}{ Sex } & \multicolumn{4}{|c|}{ Time Interval } & \multirow{3}{*}{$\begin{array}{c}\text { Difference A-B } \\
\pm \text { S.E. of } \\
\text { Difference }\end{array}$} \\
\hline & & \multicolumn{2}{|c|}{$<4$ Hours } & \multicolumn{2}{|c|}{$>4$ Hours } & \\
\hline & & $\begin{array}{l}\text { Av. Age } \\
\text { (A) }\end{array}$ & $\begin{array}{l}\text { No. of } \\
\text { Patients }\end{array}$ & $\begin{array}{l}\text { Av. Age } \\
\text { (B) }\end{array}$ & $\begin{array}{l}\text { No. of } \\
\text { Patients }\end{array}$ & \\
\hline $\begin{array}{l}\text { Mild .. } \\
\text { Mod./severe }\end{array}$ & $\begin{array}{l}\text { M. } \\
\text { F. } \\
\text { M. } \\
\text { F. }\end{array}$ & $\begin{array}{l}51 \cdot 9 \\
56 \cdot 3 \\
57 \cdot 1 \\
51 \cdot 7\end{array}$ & $\begin{array}{r}36 \\
6 \\
20 \\
3\end{array}$ & $\begin{array}{l}56 \cdot 6 \\
64 \cdot 0 \\
58 \cdot 6 \\
62 \cdot 5\end{array}$ & $\begin{array}{r}29 \\
9 \\
42 \\
15\end{array}$ & $\begin{array}{l}-4 \cdot 7^{*} \pm 2 \cdot 26 \\
-7.7 \pm 6.24 \\
=1.5 \pm 2.48 \\
-10.8 \pm 5.86\end{array}$ \\
\hline
\end{tabular}

*Significant at $\mathrm{P}<0.05$.

The percentage survival rate related to the time interval between the onset of symptoms and the initial episode of ventricular fibrillation is shown in the Chart. Patients having ventricular fibrillation within four hours of the onset of symptoms had a better long-term prognosis than those in whom it occurred later. This was significant at the first, second, and third year of follow-up $(P<0.05)$. The average age of the men who survived uncomplicated ventricular fibrillation occurring

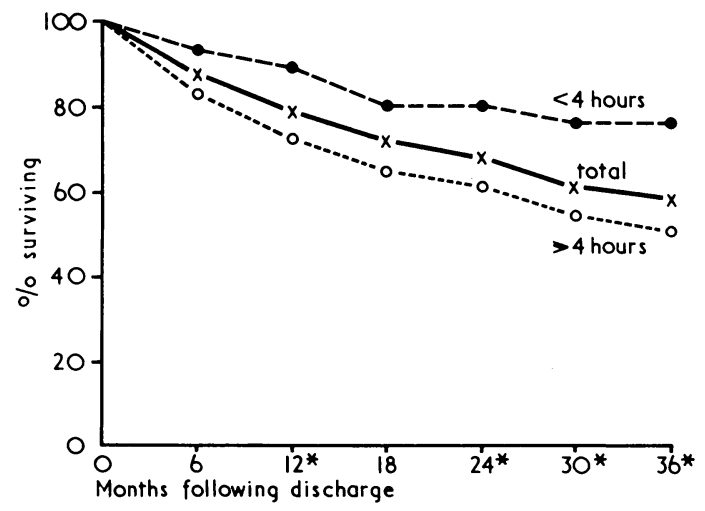

Survival of patients who had ventricular fibrillation less than four hours after the onset of symptoms is better than that of patients who had ventricular fibrillation later. within four hours of the onset of symptoms was significantly lower than that of those who had this after four hours $(\mathrm{P}<0.05)$ (Table V).

\section{Causes of Death}

The mode of death was known in 40 of the 45 patients who died after discharge; of these, four were from non-cardiac causes, while fifteen were sudden and unexpected, four of these patients having had a mild coronary attack. Five of the 11 who had had a moderate or severe attack died within one month of discharge from hospital and three of these five had been discharged on procainamide.

\section{Follow-up}

Of the 101 patients who were reviewed 30 had complained of mild angina since hospital discharge, seven of moderate angina, and three of severe; 61 had had no chest pain; four had had mild exertional dyspnoea, 41 moderate exertional dyspnoea, and 5 were dyspnoeic at rest, two of the last having emphysema; 51 had no dyspnoea; two had atrial fibrillation and three others had frequent ventricular extrasystoles; four were in mild congestive failure; and a further five had radiological evidence of left ventricular enlargement and increased pulmonary vascularity. Twenty-one patients were on oral procainamide; L.E. cells were found in the serum of one of these and in one who had stopped procainamide six months previously.

Ten patients had developed psychiatric symptoms after correction of ventricular fibrillation-seven were depressed and three had anxiety symptoms-and in only one were the symptoms severe enough to require psychiatric treatment.

\section{Readmission}

Of the 115 survivors 28 were known to have had further hospital admissions; three of these had ventricular fibrillation during the second admission-as a complication of left ventricular failure in one and of reinfarction in two. The other causes of readmission were acute myocardial infarction (2), acute coronary insufficiency (12), left ventricular failure (3), congestive heart failure (1), abdominal aneurysm successfully resected (1), sensitivity to procainamide (2), cerebrovascular accident (1), herpes zoster (1), deep venous thrombosis (1), and pemphigoid (1).

\section{Rehabilitation}

Of the 115 survivors, 15 were convalescent; 32 over 65 years had retired, and three aged 64 opted to retire. Thus 65 patients were eligible to return to work; of these $39(60 \%)$ had returned to their original work and five $(8 \%)$ to light work. Twelve $(18 \%)$, including six manual labourers, were unable to return to their previous employment and were seeking light work. Nine $(14 \%)$ were unfit to work-one had rheumatoid arthritis, one disseminated sclerosis, one cerebral damage following resuscitation, and six were unable to return to work because of their cardiac condition. Thus 7 of the 65 were unable to return to work because of their cardiovascular state.

\section{Recurrent Dysrhythmia}

Six patients, of whom all had had anterior myocardial infarction, survived six or more episodes of ventricular fibrilla- 
tion, including two who had had more than 100 episodes. Four of the six had had a mild coronary attack. The first episode of ventricular fibrillation in five of these six patients occurred 12 days or more after the onset of the coronary episode. All six were well at time of review-two had returned to work, two were seeking work, one was convalescent and one aged 66 had retired.

\section{Discussion}

The data presented here confirm our previous findings (Geddes et al., 1967), that the long-term prognosis of patients with a clinically mild coronary attack complicated by ventricular fibrillation was similar to that of patients whose coronary episode was not complicated by this. Furthermore, the prognosis of patients with a mild coronary episode complicated by ventricular fibrillation is similar to that in patients under the age of 65 with a first myocardial infarction uncomplicated by ventricular fibrillation (Pell and D'Alonzo, 1964). These authors showed that $90.5 \%$ of such patients were alive at the end of the first year, $87 \%$ at two years, and $83 \%$ at three years after discharge from hospital. Beard et al. (1967) reported similar figures for patients with a first myocardial infarction. Honey and Truelove (1957) indicated that among "good risk" patients, $94 \%$ survived one year and $88 \%$ two years.

The risk of developing ventricular fibrillation is greatest immediately after the onset of the acute coronary episode (Pantridge and Geddes, 1967). Of the 160 survivors in this present study, 96 had ventricular fibrillation within 24 hours of the onset of symptoms, 65 of them having it within four hours. The patients who survived ventricular fibrillation which occurred within four hours of the onset of symptoms were younger and most had a mild coronary attack. The long-term survival at one, two and three years after discharge from hospital of the patients who developed ventricular fibrillation within four hours of the onset of symptoms was significantly better than in those who developed it later. Furthermore, of patients who survived ventricular fibrillation complicating a mild coronary attack more than half had this complication within four hours of the onset of symptoms, whereas of those who survived ventricular fibrillation complicating a moderate or severe coronary attack less than one-third had it within four hours.

Early prehospital coronary care is important, since, whereas the usual median delay in admission is over eight hours (McNeilly and Pemberton, 1968), 46 of the 160 patients surviving ventricular fibrillation had this complication within two hours of the onset and 65 had it within four hours. Furthermore, among the 29 survivors who had ventricular fibrillation within the first hour of the onset of symptoms, 20 had this dysrhythmia while outside hospital.

While the most rewarding results from coronary care will come from preventing or correcting early ventricular fibrillation, some success may be achieved among patients who get it later. To successfully resuscitate patients with late ventricular fibrillation a highly trained team from the hospital coronary care unit must be immediately available for correct- ing cardiac arrest in any area of the hospital. Moreover, the continued management of these patients must be undertaken in the coronary care unit. That 15 of the 45 deaths following discharge from hospital were sudden and unexpected may be related to the fact that only 4 of these 15 had had a mild coronary attack. The reported incidence of sudden death among long-term survivors of ventricular fibrillation varies. Dupont et al. (1969) reported that 7 of the 25 survivors died suddenly. The clinical severity of the myocardial infarction among these patients was not indicated. When most of the survivors have had a mild infarction the incidence of sudden death has been low. Thus Lawrie (1969) reported one sudden death among 53 survivors and Stannard and Sloman (1969) reported no sudden death among 20 survivors.

The low incidence of psychiatric disturbance reported here accords with the findings of Dupont et al. (1969), who noted that only one out of 38 survivors had psychiatric difficulty. Serious emotional disturbances following resuscitation, however, have been reported by Druss and Kornfeld (1967). The fact that these workers noted a somewhat similar incidence among patients with myocardial infarction uncomplicated by cardiac arrest suggests that the psychiatric disturbance may have been related to conditions in that unit.

Our initial experience with 50 patients suggested that the long-term prognosis was not affected adversely by the number of episodes of ventricular fibrillation (Geddes et al., 1967), and experience with a further 110 patients supports this suggestion. Our present finding that $86 \%$ of the survivors eligible to work were considered fit for work and $68 \%$ were at work, is similar to the work record of those patients who survived myocardial infarction uncomplicated br this dysrhythmia. Thus Sharland (1964) showed that of the patients under 65 years with a first infarction uncomplicated by persistent heart failure $55 \%$ had returned to work three months after the infarction and $86 \%$ after one year. In the follow-up of patients under 65 years who had had a first infarction Pell and D'Alonzo (1964) found that 70 to $80 \%$ were back at work within one year, depending on whether they were salary or wage earners.

\section{REFERENCES}

Adgey, A. A. J., Geddes, J. S., Mulholland, H. C., Keegan, D. A. J., and Pantridge, J. F. (1968). Lancet, 2, 1097

Adgey, A. A. J., et al. (1969). Lancet, 1, 1169

Beard, O. W., Hipp, H. R., Robins, M., and Verzolini, V. R. (1967) American Heart fournal, 73, 317.

Berkson, J., and Gage, R. P. (1950). Proceedings of the Staff Meetings of the Mayo Clinic, 25, 270.

Day, H. W. (1963). Diseases of the Chest, 44, 423.

Druss, R. G., and Kornfeld, D. S. (1967). fournal of the American Medical Association, 201, 291.

Dupont, B., Flensted-Jensen, E., and Sandøe, E. (1969). American Hear Fournal, 78, 444.

Geddes, J. S., Adgev, A. A. J., and Pantridge, J. F. (1967). Lancet, 2, 273.

Honey, G. E., and Truelove, S. C. (1957). Lancet, 1, 1209.

Lawrie, D. M. (1969). Lancet, 2, 1085.

Lawrie, D. M., et al. (1968). Lancet, 2, 523

McNeilly, R. H., and Pemberton, J. (1968). British Medical Fournal, 3, 139.

Meltzer, L. E., and Kitchell, J. B. (1966). Progress in Cardiovascular Diseases, 9,50 .

Pantridge, J. F., and Geddes, J. S. (1966). Lancet, 1, 807.

Pantridge, J. F., and Geddes, J. S. (1967). Lancet, 2, 271

Pell, S., and D'Alonzo, C. A. (1964). New England Medical fournal, 270, 915

Sharland, D. E. (1964). British Medical Fournal, 2, 718

Stannard, M., and Sloman, G. (1969). American Heart fournal, 77, 573. 